\section{Transmission of Xylella fastidiosa to Oleander by the Glassywinged Sharpshooter, Homalodisca coagulata}

\author{
H.S. Costa ${ }^{1}$, M.S. Blua, J.A. Bethke, and R.A. Redak \\ Department of Entomology, University of California, Riverside, CA 92521
}

Additional index words. cultivar, Insecta, leafhopper, Nerium oleander, oleander leaf scorch, sharpshooter, vector

\begin{abstract}
Studies were conducted to investigate the transmission of the oleander leaf scorch (OLS) pathogen to oleander (Nerium oleander L.) plants by sharpshooters. OLS is incited by a strain of the bacterial plant pathogen Xylella fastidiosa Well. The glassywinged sharpshooter, Homalodisca coagulata (Say), is a principal vector of this pathogen in California. In these studies, three cultivars of oleander were exposed to sharpshooters that had previously fed upon OLS-infected oleander plants. Sharpshooters were subsequently caged on healthy oleander plants individually or in groups of three. Plants were observed for symptoms of disease, and ELISA was used to test for the presence of $X$. fastidiosa. The probability of infection did not differ significantly when plants were inoculated with one insect $(83 \%)$ or with three $(94 \%)$. However, higher plant mortality rates were observed on plants inoculated with three insects, indicating that a greater number of infection sites may hasten plant death. Although all oleander cultivars were equally susceptible to inoculation by sharpshooters, 'Ruby Lace' plants were less symptomatic and had a higher level of survival after one year than 'Hardy Pink' and 'Hardy Red'. When given a choice of the three cultivars to feed on, the number of insects feeding did not differ among cultivars at 24 or $\mathbf{4 8}$ hours after exposure.
\end{abstract}

Oleander plants are an important component of landscape horticulture in the southwestern United States. In addition to decorative uses for home landscaping, shopping centers, parks and golf courses, oleanders play an important role as windbreaks, borders, and freeway median plantings. Oleander leaf scorch is a disease that has recently killed numerous plantings of oleander in California and other southwestern states. Estimates indicate that the California Department of Transportation alone stands to suffer at least a $\$ 52$ million loss if they are forced to replace the more than $3300 \mathrm{~km}$ of oleander freeway plantings (Blua et al., 1999).

Symptoms of oleander leaf scorch include marginal leaf scorching, leaf tip burn, chlorotic spotting or striping on leaves, wilting, and death (Purcell et al., 1999). The causal agent is Xylella fastidiosa, a xylem-limited bacterium originally described by Wells et al. (1987), that blocks the vascular tissue of plants. Various strains of this organism induce a variety of other diseases including Pierce's disease of grape (Vitus sp.), almond [Prunus dulcis (Mill.) D. A. Webb] leaf

\footnotetext{
Received for publication 21 Dec. 1999. Accepted for publication 28 Mar. 2000. We thank M. Grebus and S. Campbell (Department of Plant Pathology), and K. Kido (Department of Entomology) for technical assistance. This research was funded in part by the California Association of Nurserymen. The cost of publishing this paper was defrayed in part by the payment of page charges. Under postal regulations, this paper therefore must be hereby marked advertisement solely to indicate this fact.

${ }^{1}$ E-mail address: hcosta@pop.ucr.edu
}

scorch, peach [Prunus persica (L.) Batsch.] phony disease, plum (Prunus sp.) leaf scald, and citrus varigated chlorosis (Hartung et al., 1994; Hopkins, 1977, 1989; Pooler and Hartung, 1995).

The pathogen is primarily transmitted by leafhopper insects commonly known as sharpshooters (Homoptera: Cicadellidae). In southern California, the two major vectors of this pathogen to oleander are the glassywinged sharpshooter, a recent introduction from the southeastern United States (Sorensen and Gill, 1996), and the smoke tree sharpshooter, Homalodisca lacerta (Fowler), which is native to southern California. These insects have a wide host range; $H$. coagulata has been reported to feed on 75 species of plants in 35 families (Turner and Pollard, 1959). The insects are xylem feeders, allowing them to acquire and transmit xylem-limited bacteria during feeding activity. In the glassywinged sharpshooter, $X$. fastidiosa bacteria were observed in the cibarium, the apodemal groove of the diaphragm, and the walls of the precibarial area (Brlansky et al., 1983). In another leafhopper species, Graphocephala atropunctata (Signoret), this bacterium was most consistently isolated from the foregut, infectivity was lost after molting, and no latent period was observed. This suggests a noncirculative mechanism of transmission (Purcell, 1990; Purcell and Finlay, 1979). The bacterium multiplies in the mouthparts of the insect, so once the insect acquires it as an adult, it retains the pathogen for the remainder of its life (Brlansky et al., 1983; Purcell and Hopkins, 1996). Purcell et al. (1999) described sharpshooter transmission of $X$. fastidiosa to oleander but were unable to determine transmission efficiency.

The specific objectives of this study were to determine: 1) the rate of transmission of the OLS organism by the sharpshooter vector $H$. coagulata to oleander; 2 ) if there is a difference in susceptibility of selected oleander cultivars to infection as measured by rate of inoculation, symptom severity, and plant mortality; and 3) if there are any preferences by $H$. coagulata for selected oleander cultivars.

\section{Materials and Methods}

Three cultivars of oleander, Nerium oleander (Apocynaceae) were used: 'Hardy Pink', 'Hardy Red', and 'Ruby Lace'. Twentyfive plants of each cultivar, propagated by cuttings, were grown in 4-L containers under greenhouse conditions for 6 months. Plants were watered daily and fertilized with slow release fertilizer (Osmocote $18 \mathrm{~N}-6 \mathrm{P}-12 \mathrm{~K}$; Scotts-Sierra, Marysville, Ohio). All test plants were tested for infection by $X$. fastidiosa using commercial ELISA test kits (Agdia, Elkhart, Ind.) and found to be free of Xylella prior to initiation of the study.

$H$. coagulata adults were collected from citrus orchards on the campus of the Univ. of California, Riverside, and caged on infected oleander source plants for $7 \mathrm{~d}$ to allow acquisition of the bacterial pathogen. Adults were then collected from infected plants and placed on new healthy plants, individually or in groups of three, using soft cloth cages $(45 \times$ $45 \mathrm{~cm}$ ) covering the entire plant and secured around the top of the pot with a rubber band. Insects were allowed to feed on healthy test plants for $5 \mathrm{~d}$, after which they were removed. Inoculated plants were maintained in the greenhouse.

At 4 and 10 months after inoculation, leaves from each plant were sampled from the middle and top sections and tested for infection by $X$. fastidiosa using the same ELISA test kits. A 3-cm length of leaf midvein, from the petiole end, was chopped into minute pieces on a clean glass slide and placed into a $1.5 \mathrm{~mL}$ centrifuge tube containing $1 \mathrm{~mL}$ of extraction buffer on ice $(1000 \mathrm{~mL}$ phosphatebuffered saline with Tween [PBS-Tween from kit], $1.3 \mathrm{~g}$ sodium sulfite, $20 \mathrm{~g}$ polyvinyl pyrrolidone (PVP), $0.2 \mathrm{~g}$ sodium azide, $2 \mathrm{~g}$ powdered chicken albumin, $20 \mathrm{~g}$ Tween- $20^{\circledR}$, $\mathrm{pH}$ adjusted to 7.4. Tubes were stored overnight under refrigeration, and samples of extract were tested using instructions provided in the kit. An absorbance measurement (A490 nm) of samples was made using an automatic ELISA plate reader. Samples were considered positive if they measured at least twice the mean absorbance of healthy oleander controls. The probability of infection with one or three insects was compared using the Fisher's exact test (SAS Institute, 1990).

Nine months after inoculation, symptoms were rated on a scale from $0-3(0=$ no symptoms, $1=$ slight leaf chlorosis, $2=$ significant leaf chlorosis, 3 = leaf necrosis). Mean symptom severity ratings were com- 
pared among oleander cultivars and between plants inoculated with one or three insects using the Kruskal-Wallis test followed by the Mann-Whitney test (Minitab, 1996) to separate treatment means when necessary. Percentage of plant survival after 1 year was compared among cultivars of oleander using the Fisher's exact test, and between the number of insects used to inoculate the plants using a chi square analysis (Minitab, 1996).

Feeding preference. The same three oleander cultivars used above were used in a host feeding preference test. Plants were potted in $10-\mathrm{cm}$ pots $(600 \mathrm{~mL})$ and allowed 8 weeks growth on raised benches in greenhouses before use. All plants were fertilized once a week $\left(150 \mathrm{mg} \cdot \mathrm{L}^{-1} \mathrm{~N}\right.$ Stern's Miracle Gro Products, Port Washington, N.Y.) and irrigated every other day by drip irrigation. One of each of the three cultivars of oleander was placed in a cylindrical acetate cage (40 $\mathrm{cm}$ wide $\times 70 \mathrm{~cm}$ tall) with a screened top (32 $\times 32$ mesh; Chicopee Lumite, Gainesville, $\mathrm{Ga}$.) for ventilation. Five replicate blocks (a cage with three plants, one of each cultivar) were established.

Twenty H. coagulata adults collected from citrus trees (Univ. of California, Riverside) were placed in each cage. Observations of the locations of sharpshooters (on which of the three plant cultivars, on cage wall, or dead) were made at 24 and $48 \mathrm{~h}$. Data were analyzed using a log-linear model (G-test for independence; Catmod Proc, SAS Institute, 1990). Williams' correction was used to correct for small sample size (Sokal and Rohlf, 1981).

\section{Results}

Infection rate among cultivars. Four months after inoculation, $88 \%$ of the 75 inoculated plants tested positive for infection by $X$. fastidiosa (80\% of 'Hardy Pink', 96\% of 'Hardy Red', and $88 \%$ of 'Ruby Lace'). The probability of infection was not significantly different among cultivars (Fisher's exact test results: 'Hardy Pink' vs. 'Hardy Red' $P=0.19$, 'Hardy Red' vs. 'Ruby Lace' $P=0.61$, 'Hardy Pink' vs. 'Ruby Lace' $P=$ 0.70 ). ELISA tests were repeated 10 months after inoculation with similar $(89 \%$ infection) results. The probability of infection by inoculation with one insect ( $83 \%$ inoculation) did not differ significantly from that with three insects (94\% inoculation) (data not shown, Fisher's exact test $P=0.19$ ).

Symptom severity. Nine months after inoculation, symptom ratings were significantly lower on 'Ruby Lace' $(1.6 \pm 0.13$, mean \pm SEM) than on 'Hardy Pink' $(2.6 \pm 0.20)$ or 'Hardy Red' (2.8 \pm 0.10$)$ (Fig. 1A) (Kruskal-Wallis $H=3.24$, $\mathrm{df}=2, P \leq 0.001$, followed by Mann-Whitney Test, 'Hardy Pink' vs. 'Hardy Red' $P=0.84$, 'Hardy Pink' vs. 'Ruby Lace' $P \leq 0.001$, 'Hardy Red' vs. 'Ruby Lace' $P \leq 0.001$ ). Visual symptom ratings did not differ significantly in plants inoculated with three $(2.6 \pm 0.12$, mean \pm SEM $)$ vs. one insect $(2.2 \pm 0.15)$ (Kruskal-Wallis $H=$ 3.05 , df $=1, P=0.08$ ).

Plant mortality. One year after inoculation, more than half of the 'Hardy Pink' and
'Hardy Red' plants had died, while none of the 'Ruby Lace' plants died (Fig. 1B). In addition, 'Ruby Lace' plants had a significantly higher probability of surviving than did the other cultivars tested (Fisher's exact test results: 'Hardy Pink' vs. 'Hardy Red' $P=0.78$, 'Hardy Pink' vs. 'Ruby Lace' $P \leq 0.001$, 'Hardy Red' vs. 'Ruby Lace' $P \leq 0.001)$. Plants inoculated with three insects had a significantly higher probability of dying (chi-square $P=0.02$ ) than did those inoculated with one insect; $52 \%$ of plants inoculated with three insects died vs. $26 \%$ of those inoculated with one insect.

Feeding preference. There were no significant differences among oleander cultivars in feeding preference by $H$. coagulata $(\mathrm{G}=2.69 ; P=0.26)$, and time after exposure $(24$ vs. $48 \mathrm{~h}$ ) did not affect the number of insects feeding on a single cultivar $(\mathrm{G}=0.92$; $P=0.34)$.

\section{Discussion}

In this study, the rate of infection of each oleander cultivar was high. Even when only one insect was used to inoculate a plant, $83 \%$ of plants became infected after $5 \mathrm{~d}$ of expo-
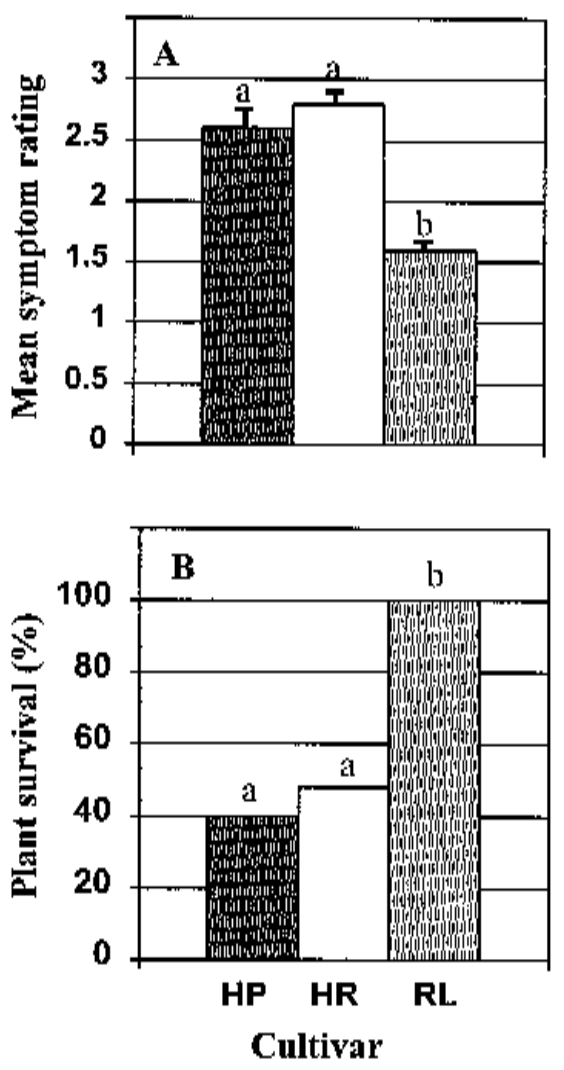

Fig. 1. Symptom severity ratings (scale of $0-3$ ) of three cultivars of oleander (A) 9 months after inoculation with Xylella fastidiosa, and (B) percentage of plants surviving 1 year after inoculation. $\mathrm{a}, \mathrm{b}=$ mean separation by: $(\mathbf{A})$ Kruskal-Wallis followed by Mann-Whitney test, $P \leq 0.001$; and (B) Fisher's exact test $P \leq$ 0.001. HP = 'Hearty Pink', HR = 'Hearty Red', $\mathrm{RL}=$ 'Ruby Lace'. sure. Higher mortality rates were observed on plants that were inoculated with three insects, indicating that a greater number of inoculation sites may hasten plant death. In these trials, infected sharpshooters were confined and forced to remain on plants for $5 \mathrm{~d}$. Transmission efficiency by individual insects may be much lower under natural conditions where insects can move from plant to plant unrestrained. Under natural conditions, however, numerous sharpshooters may feed on one plant at one time.

Although all cultivars were equally susceptible to inoculation by sharpshooters, 'Ruby Lace' plants were less symptomatic and had a higher level of survival after 1 year. The varied response of oleander cultivars to $X$. fastidiosa infection suggests that cultivars that are relatively resistant to or tolerant of infection already exist. We found differences in tolerance to oleander leaf scorch by randomly examining only three cultivars of oleander. Note, however, that in this study even the cultivar that showed low levels of symptoms and appeared fairly healthy was still infected as frequently as the other cultivars. Nonsymptomatic plants may possibly serve as sources of pathogen inoculum for vectors to infect susceptible hosts in the surrounding environment (Hopkins, 1989; Purcell and Hopkins, 1996). Further studies are needed to determine if cultivars of oleander that show less severe symptoms still serve as good sources of inoculum.

There was no indication that insects preferred to feed on any one of the three cultivars tested. When three cultivars were available to feed on, the number of insects feeding on each cultivar at 24 or $48 \mathrm{~h}$ after exposure did not differ. Differences in symptom severity were probably not the result of fewer insects feeding on 'Ruby Lace' than on the other cultivars.

Because glassywinged sharpshooters have such a broad host range and a potential for such high rates of transmission, attempts to control this disease simply by reducing the number of vectors in the environment are unlikely to be effective. Certain pesticides have been found to kill sharpshooters exposed to treated plants within 2-3 min (J.A. Bethke, unpublished data). Further study will be necessary to determine the length of time required for insects to inoculate plants in order to establish if methods aimed at interrupting transmission, such as use of systemic pesticides, would be effective in preventing inoculation.

Currently, in addition to the direct threat of $X$. fastidiosa to oleander plantings, the broad host range of both the vector and pathogen raises concerns about the potential for pathological infection of other landscape plants and agricultural hosts. Although no evidence is available that the oleander strain of $X$. fastidiosa can systemically infect other agriculturally important crop species, as with other strains of $X$. fastidiosa, other agriculturally important crops may be at risk from this strain (Hopkins, 1977; Purcell and Hopkins, 1996). Further research needs to be conducted to determine which plant species 
are at risk from this strain of $X$. fastidios $a$, and to identify the species that can serve as nonpathological reservoirs of the bacteria (Blua et al., 1999).

\section{Literature Cited}

Blua, M.J., P.A. Phillips, and R.A. Redak. 1999. A new sharpshooter threatens both crops and ornamentals. Calif. Agr. 53:22-25.

Brlansky, R.H., L.W. Timmer, W.J. French, and R.E. McCoy. 1983. Colonization of the sharpshooter vectors, Oncometopia nigricans and Homalodisca coagulata, by xylem-limited bacteria. Phytopathology 73:530-535.

Hartung, J.S., M.J.G. Beretta, R.H. Brlansky, J. Spisso, and R.F. Lee. 1994. Citrus variegated chlorosis bacterium: Axenic culture, pathogenicity, and serological relationship with othe strains of Xylella fastidiosa. Phytopathology 84:591-597.
Hopkins, D.L. 1977. Diseases caused by leafhopper-borne, rickettsia-like bacteria. Annu. Rev. Phytopathol. 17:277-294.

Hopkins, D.L. 1989. Xylella fastidiosa: Xylemlimited bacterial pathogen of plants. Annu. Rev. Phytopathol. 27:271-290.

Minitab Inc. 1996. Minitab reference manual, Release 11. Minitab, State College, $\mathrm{Pa}$

Pooler, M.R. and J.S. Hartung. 1995. Specific PCR detection and identification of Xylella fastidiosa strains causing citrus variegated chlorosis. Curr. Microbiol. 31:377-381.

Purcell, A.H. 1990. Homopteran transmission of xylem-inhabiting bacteria, p. 243-266. In: Advances in disease vector research, Vol. 6 Springer-Verlag, New York.

Purcell, A.H. and A.H. Finlay. 1979. Evidence for noncirculative transmission of Pierce's disease bacterium by sharpshooter leafhoppers. Phytopathology 69:393-395.

Purcell, A.H. and D.L. Hopkins. 1996. Fastidious xylem-limited bacterial plant pathogens. Annu.
Rev. Phytopathol. 34:131-151.

Purcell, A.H., S.R. Saunders, M. Hendson, M.E. Grebus, and M. J. Henry. 1999. Causal role of Xylella fastidiosa in oleander leaf scorch disease. Phytopathology 89:53-58.

SAS Institute. 1990. User's manual. Version 6, SAS Institute, Cary, N.C.

Sokal, R.R. and S.J. Rohlf. 1981. Biometry. W.H. Freeman, New York.

Sorensen, J.T. and R.J. Gill. 1996. A range expansion of Homalodisca coagulata (Say) (Hemiptera: Clypeorrhncha: Cicadellidae) to southern California. Pan-Pacific Entomol. 72:160-161.

Turner, W.F. and H.N. Pollard. 1959. Life histories and behavior of five insect vectors of phony peach disease. U.S. Dept. Agr. Tech. Bul. 1188.

Wells, J.M., B.C. Raju, H.Y. Hung, W.G. Weisburg, L. Mandelco-Paul, and D.J. Brenner. 1987. Xylella fastidiosa gen. nov., sp. nov.: Gramnegative, xylem-limited, fastidious plant bacteria related to Xanthomonas sp. Intl. J. System. Bacteriol. 37:136-143. 